\title{
Service Development in Outsourced Public Service Networks: A Study in the Public Transport Sector
}

\author{
Patrik Gottfridsson \\ Service Research Center, Karlstad University \\ SE-651 88 Karlstad, Sweden \\ E-mail: Patrik.Gottfridsson@kau.se \\ Carolina Camén \\ Service Research Center, Karlstad University \\ SE-651 88 Karlstad, Sweden \\ E-mail: Carolina.camen@kau.se
}

Received: February 2, 2012

Accepted: March 8, 2012

Published: May 1, 2012

doi:10.5539/ibr.v5n5p26

URL: http://dx.doi.org/10.5539/ibr.v5n5p26

\begin{abstract}
When public-sector services are outsourced to private commercial operators, the issue of new-service development can become problematical because the political/social objectives of the controlling authority are often different from the commercial imperatives of the private operator. These (often conflicting) imperatives can cause difficulties in new-service development with regard to both: (i) deciding what new services are required; and (ii) deciding how the service-development process should proceed. This study takes a qualitative approach in investigating what happens during the development of new services in the Swedish public-transport sector, in which services are contractually outsourced from public authorities to private commercial operators by public tender. The results of the study show that: (i) the development of new services in this context is especially challenging; (ii) conflicts do arise between public and commercial interests; (iii) collaborative service development is significantly hampered by the regulatory framework and contractual arrangements; and (iv) the contracts themselves actually represent an important aspect of the overall service-development process. The implication for managers is that the formulation of tendering documents and contracts must be seen as an important determinant of service development, often for many years in advance.
\end{abstract}

Keywords: Service development, Innovation network, Public transport, Public tendering

\section{Introduction}

Developing services is one of the most important factors in securing the future success of virtually all commercial organisations (de Brentani, 1989; Cooper, 1996; Johne \& Storey, 1998; Cooper \& Edgett, 1999). As de Brentani (1989, p. 239) has observed:

Intense competition, changes in technology and an economy that increasingly relies on services for expansion has made the successful development of new services a key to success for many firms.

New ideas to improve the customer offering have traditionally been a feature of commercial settings, in which it is clearly important to satisfy the customers' needs and wants (Edvardsson, 1996). However, in some contexts, the situation is somewhat different because the development of new services with a view to increasing earnings is not necessarily the primary imperative of the organisation. One such context is the public sector, in which the goals of service organisations tend to be based on efforts to meet the common goals of society in general, rather than commercial goal of earning more money for one particular organisation. Indeed, the development of new services in public-sector organisations is often subject to legal constraints and/or the edicts of government policy-makers whose aim is to deliver services that best meet the needs of society in general, rather than the desires of specific organisations and/or customers. 
In some contexts these two imperatives are not mutually exclusive. For instance, public services sometimes compete with other providers (public and/or private) in serving customers who have other consumption alternatives. The public-transport sector is a good example of such a setting. In this sector, government usually has overall responsibility for providing a legislative framework for ensuring the quality of the transport services being delivered. Government also often takes responsibility for the overall development of the sector, as in the case of the Swedish public-transport service (SLTF, 2002). As a consequence, public-transport services in many countries are, to a large extent, determined by a national political agenda that takes into account a variety of broad societal considerations.

In the case of the Swedish public-transport system, the central government's policy is operationalised by a public-sector body known as a Public Transport Authority (PTA), which is responsible for the service provided in a specific geographical area. The actual services (that is, the actual vehicular transport) are provided by external sub-contractors, which are selected by a public tendering process regulated by the Swedish Public Procurement Act (SFS, 1992, p. 1528). Relevant requirements of this Act include:

- the contractual criteria must be clearly specified in advance of the tendering process;

- previous experience with a particular contractor and/or existing relationships between the parties must not influence the selection of the successful sub-contractor; and

- the price offered by potential sub-contractors, given a certain level of service, must be the determining consideration in deciding which sub-contractor is selected to receive a contract.

Typical contracts between a PTA and a successful tenderer extend for 5-10 years. Whatever the duration of a given contract, all relationships must be terminated on a specific expiry date, at which time a new public tendering must be held. For the purposes of the next tender, new contracts must be developed, written, and signed.

The contractual relationship between the PTA and the sub-contractors is a good example of the conflicting imperatives noted above. The sub-contractors are external commercial organisations whose imperative is to make a profit through their contracted business. Indeed, in many instances, they are large commercial companies that have simultaneous sub-contractual relationships with several different PTAs. Because their priority is to maximise profits by optimising the distribution of their resources among their various contracts, these sub-contractors are thus driven by a different logic from that of the central government. This places the PTAs in the delicate position of acting as intermediaries between political/social actors and commercial actors, each of whom has a different (and sometimes incompatible) agenda.

\subsection{Research Question}

Against this background, an important question that arises is how new services are developed in such a setting. In other words, what happens in new-service development when commercial imperatives and public imperatives meet each with different incentives for developing new services? This broad question of 'what happens' can be subdivided into two more specific research questions:

- What is developed in these situations? and

- How are these developments undertaken?

The aim of the present study is to address these two research questions in the context of the Swedish public-transport system. In doing so, seven empirical cases are qualitatively examined and analysed.

The remainder of this paper is structured as follows. The next section presents a review of the relevant literature on service development and innovation networks to establish the theoretical foundations of the study. The following section describes the methodology of the qualitative empirical study of seven cases in the Swedish public-transport sector. The results of the empirical study are then presented. The paper concludes with a summary of the major findings and the managerial implications.

\section{Theoretical Framework}

\subsection{Service Development}

Service development (and product development for that matter) can be categorised in several ways, depending on the perspective that is adopted. For example, from a customer or market perspective, Lovelock's (1984) classification of innovations and developments consists of six categories:

- major innovations: new products/services for markets as yet undefined;

- start-up businesses: new products/services for markets that are already served by existing products that meet the same generic criteria; 
- new products for the currently served market: new products/services that attempt to offer existing customers of an organisation a product not previously available to them from that provider;

- product line extensions: new products/services that represent an augmentation of the existing product/service;

- product improvements: changes in certain features of existing products currently on offer to the currently served market; and

- style changes: highly visible changes to existing products.

Another perspective on service development is to focus on whether the development is in the core-service (that is, directed at a new solution to the actual problem to be solved) or whether it is in the supporting services (that is, directed at the services that augment the already established solution). In the second case, the notion of 'service development' can include either the addition of new services (for example, lounges, internet access, etc.) or the removal of some supporting services (as occurs in low-price airlines). This wider understanding of 'service development' is obviously relevant to public-transport services, which are the focus of the present study.

Several models have been suggested to describe how services are (or at least ought to be) developed. According to Johnson et al. (2000), these models can be divided into three broad categories:

- partial models, which focus on a specific aspect of the service-development process - for example, how to generate ideas (Kristensson, 2003) or how to involve customers in the development of services (Sandén, 2007; Matthing, 2004);

- translational models, which draw on the principles of new-product development and translate this into new-service development (Booz et al., 1982); and

- comprehensive models, which aim to provide a holistic view of the service-development process (Johnson et al., 2000).

According to several extensive reviews of the literature, most of these models focus on the actors and resources within the organisation and on how various stages of the development process are carried out, or should be carried out (Johne \& Storey, 1998; Akamavi, 2005; Jong \& Vermeulen, 2003). In addition, Lievens et al. (1999) have noted that most of the models also posit service development as a sequential process consisting of at least three broad phases: (i) a planning stage; (ii) a development stage; and (iii) a market launch stage.

However, although the extant models usually describe such a structured process consisting of various sequential phases, several authors have argued that the actual service-development process in real life is seldom as structured and formalised as these models would suggest (Johne \& Storey, 1998; Edgett, 1996; Martin \& Horne, 1993; Bowers, 1989).

\subsection{Innovation Networks}

Schilling and Werr's (2009) extensive review of the literature on service innovation identified the management of network relationships as one of the most important aspects of the service-development process. Just as interaction and co-operation among various actors represents a vital component of any service offering (Grönroos 1990), the service-development process itself proceeds on the basis of interactive co-operation and exchanges of information among various sets of actors (Johne \& Storey, 1998; Syson \& Perks, 2004; Johansson \& Vahlne, 1992).

According to Schilling and Werr (2009), service firms that wish to be innovative must think of themselves as part of an innovation network in which they interact and exchange resources, knowledge, and ideas with actors in their environment, such as customers and innovation partners. To manage such a network, these various actors must be involved in a way that facilitates communication and creates a climate in which actors feel motivated to contribute and be creative.

The notion of an innovation network thus casts some doubt on the conventional view of service development as a sequential process; in its place, the network perspective posits service development as a series of problems to which the organisation must find solutions if it is to develop a new offering (Stevens \& Dimitriadis, 2004). As Stevens and Dimitriadis (2004, p. 1075) have observed, the process of new service development is:

... a cooperative, interactive, [but] not very formalized process, involving actors from different departments of the company ... [whereby] the organisational structure, the communication networks and the working processes are transformed...

\subsection{The Role of Customers and Front-line Employees in Service Development}

It is logical, from a theoretical perspective, to involve customers in the service-development process. As Edvardsson (1997, p. 33) have pointed out: "Attractive and customer-friendly services emerge from a dialogue with competent 
and demanding customers". Involvement of the users makes theoretical sense because their ideas for new services are likely to be perceived as being more useful than services developed solely by professional developers. However, there is some empirical evidence that the new service ideas suggested by customers tend to be generally less feasible to produce (Magnusson et al., 2003), and although it would seem that customers should be a valuable source of information (Abramovici \& Bancel-Charensol, 2004), the reality is that they are seldom much involved in the service-development process (Edvardsson et al., 2000; Sundbo, 1997, 1998).

It would also seem to be logical to involve front-line employees in the service-development process. Because they are exposed to customers and customer needs on a regular basis, front-line employees are commonly assumed to possess knowledge that can be beneficial for successful service innovation. It has therefore been suggested that service firms should recruit and retain experienced and insightful front-line employees who have been exposed to customer needs and can therefore bring valuable knowledge into the organisation (Leiponen, 2005). However, to achieve maximum benefit from these front-line employees, it is necessary for them to be released (at least to some extent) from their ordinary day-to-day tasks in order to spend time on the innovation process.

\section{Research Methodology}

\subsection{Sample and Data Collection}

The present study adopted a qualitative case-study methodology to investigate what happens in new-service development when commercial imperatives and public imperatives meet - each with different incentives for developing new services. A case-study approach (Yin, 1994) using data from a seven cases within the Swedish public-transport sector was adopted because service development is a fairly new area, in which rich qualitative data from case studies are considered more appropriate for theory building than theory testing (Johne \& Storey, 1998; Syson \& Perks, 2004; Daymon \& Holloway, 2002; Merriam, 1994; Eisenhardt, 1989).

The primary data were derived from interviews with representatives from several Swedish PTAs and sub-contractors. All of the interviewees occupied positions of responsibility for the development and delivery of public-transport services - including general managers, business managers, and traffic planners from the PTAs, and members of boards of management, presidents, and business unit managers of the sub-contractors. The interviews were conducted during 2005 and 2006 at various locations in Sweden. A semi-structured interview guide was used to provide the interviewees with opportunities to speak freely on the subjects being canvassed. The duration of the interviews varied from 30 minutes to 150 minutes. Selection of the PTAs and sub-contractors was made by means of intentional sampling of information-rich cases (Patton, 1990).

Secondary documentary data were also collected. These data were gathered from: (i) laws and regulations governing the public-transport sector in Sweden; (ii) government reports and statements regarding the guidelines and regulations for the sector; and (iii) information from the Swedish Public Transport Association (SLTF), which is the trade association for the public-transport authorities.

The data were analysed using open coding of the transcribed interviews, supplemented with data from the documentary study (Miles \& Huberman, 2004).

\subsection{The Cases}

Seven case studies were conducted. The first case involved a PTA in northern Sweden, which had contracts with approximately 35 bus contractors and a large number of taxi entrepreneurs. The County Council owned $50 \%$ of this PTA, with the remaining $50 \%$ being owned by the municipalities in the county.

The second case involved a PTA in central Sweden, which had contracts with three bus contractors, a sub-contractor for rail traffic, and 30 taxi entrepreneurs. This PTA was owned by ten municipalities in the county and the Country Council.

The third case involved a PTA in south-west Sweden, which had contractual arrangements with one big bus operator, a number of smaller bus operators, and several taxi operators. This PTA was also owned by the County Council and municipal authorities.

The fourth case involved a PTA in southern Sweden, which had contracts with 25 sub-contractors and a number of taxi entrepreneurs. This PTA was jointly owned by the County Council and the county's thirteen municipalities.

The fifth case involved a PTA in central Sweden. This PTA was responsible for the inner-city traffic in only one city (the region's largest city). For this purpose, the PTA had one contract with a large bus operator and 10-15 contracts with smaller taxi-entrepreneurs.

The sixth case was somewhat different from the preceding cases. It involved a study of the long-term (6-8 years) development of a new ticketing and information system involving collaboration among six Swedish PTAs. The 
collaboration involved: (i) a formal project group of four members with overall responsibility for the project; (ii) an advisory board consisting of managers of the PTAs; (iii) large project groups of approximately 25-30 participants representing different areas of expertise within the Swedish public-transport sector; and (iv) smaller task groups working on technical solutions to specific problems. In addition, an external technical consultancy firm was also engaged to build the actual ticketing system. The ticketing and information system was based on a joint standard created by an industrial organisation for the Swedish public-transport sector.

The seventh case concerned the long-term (5-8 years) development and implementation of a new ticketing and information system by a single PTA in one large Swedish city. The development process was conducted jointly with a technical consultancy firm that was responsible for developing the hardware and software for the project. At the beginning, the project was run by a project group, but it subsequently involved 8-10 subgroups that became responsible for developing and integrating various aspects of the system. A major challenge was ensuring that the system suited the needs of different groups of operating staff. As in the sixth case, this ticketing and information system was again based on a joint standard created by an industrial organisation for the Swedish public-transport sector.

\section{Results}

For convenience, the results of the seven case studies are presented as a comprehensive overview, rather than as specific findings from individual cases. The presentation of the findings is divided into two parts, which address each of the research questions posed in the Introduction:

- What is developed in these situations? and

- How are these developments undertaken?

\subsection{What Is Developed?}

Service development in the cases entailed a variety of large and small projects with different purposes. Three general types of development projects were discerned.

First, in all cases, the PTAs were either engaged (or had recently been engaged) in large projects to simplify and improve the ticketing and information systems used for public-transport services. For example, in the first case, the PTA was in the process of installing a new communication system in all buses to improve the exchange of information between vehicles and between vehicles and headquarters. It was envisaged that the system would enable customers to undertake booking and ticketing via the Internet. In a similar vein, all PTAs were in the process of introducing so-called 'real-time systems', which monitor all stations and show all schedules (and any delays) in real time via various channels (such as the Internet and wireless networks). These large development projects, which required significant resources and time, represented long-term strategic service-development projects that were usually undertaken in collaboration with a number of other PTAs. However, the sub-contractors (operators) were rarely (if ever) actively involved in these projects until the final implementation phase. This could be due to the time horizon for this kind of project extending beyond the duration of their contracts. Moreover, because these development projects were usually undertaken in collaboration with other PTAs, the involvement of the operators would have further complicated an already complex project involving a large number of actors.

The second type of development projects were undertaken at the behest of the owners of the PTAs to meet the broad political and social requirements of society in general without a specific focus on the day-to-day needs of public-transport customers. One example of such owner-driven development projects was a focus in all case studies to provide vehicles suitable for elderly and disabled customers. This was done because it was deemed important from a social and humanitarian perspective to facilitate the use of public transport by all citizens. Another such example was the investment made by all PTAs in environmentally friendly vehicles that produced less pollution. Because these sorts of commitments (to aged/disabled citizens and to the environment) are resource-demanding and reduce the flexibility to invest in other areas that might be more commercially attractive, they were usually specified in tendering documents and contractual obligations, backed up with fines and other sanctions if contractors did not meet the stipulations of the contracts. These types of development projects bring into focus the political struggle that always accompanies the utilisation of scarce resources in public transport. In this context, the general manager of the PTA in the fourth case revealed his sensitivity about political issues. He noted that as long as the owners of the PTA wanted to maintain strict control and as long as they perceived public transport in political and social terms, it would continue to be very difficult for the PTA to act as a purveyor of a commercial product competing in the market. In contrast to these considerations, the sub-contractors were, of course, operating as commercial entities whose purpose was to make a profit through its contracted business. As previously noted, the sub-contractors and the political/social actors were thus driven by different imperatives. 
Apart from the first two types of development (large strategic projects and the owner-driven projects), there was a third type of development that was generally less expensive and extensive. These projects extended the core service of public transport (that is, safe transport from point A to point B) by adding ancillary services to meet the secondary needs of customers. Examples from the first case study included the introduction of business class on the buses and the employment of bus attendants on some longer routes. The general manager of the PTA in the second case characterised these sorts of customer-oriented developments in the following terms:

A common theme in the developments that we undertake is ... the customer - the market perspective. We have a good product, which we will improve even more. And it must be marketed as competitively as possible.

In summary, in response to the question of what is developed in terms of service development, the present study finds that development projects were of three general kinds in these outsourced public-transport services:

- long-term and resource-intensive strategic developments;

- owner-driven developments to meet political/social objectives; and

- customer-focused projects with the aim of enhancing the competitiveness of the public-transport product.

\subsection{How Are These Developments Undertaken?}

In all cases, the interviewees emphasised the importance of cooperative relationships among all the parties involved in service provision. The general manager of the PTA in the fifth case made the following comments about this collaboration:

When we buy this kind of service, as we have contracted to do for eight years into the future, we buy a service that is produced and consumed simultaneously. This does not mean that the PTA, as a purchaser, has completed its efforts once it has purchased the service; rather, the PTA has to be an active participant every day during those eight years. Our relationship with the subcontractor is therefore very important. Because the PTA represents the brand and receives any complaints, we are very keen to ensure an effective functional relationship.

The business development manager of the same PTA supported this view with the following comment:

Our mutual goal is the satisfaction of the customer - the traveller, who uses our services. To achieve this goal, it is important not to see the contractual parties as separate actors; rather it is important to create a good cooperative relationship in which the subcontractor does not see the PTA merely as its customer. In fact, the customer is the traveller. It's all about ensuring that the traveller is satisfied.

Despite these stated commitments to cooperative collaboration in service provision, new-service development in the case studies was apparently conducted independently by one actor or the other, without any collaboration between the contracting parties. In particular, in the long-term projects to develop and implement new ticketing and information systems, service development was undertaken entirely by the PTAs (and their technical advisors) without any involvement on the part of the sub-contractors until the final implementation phase of the projects. According to the PTAs, it was difficult to work in collaboration with sub-contractors in these development projects because the sub-contractors were too conscious of the contractual and financial constraints whenever service development was being discussed. As the business-development officer at one of the PTAs put it:

There is too much focus on the contract and money. This is especially noticeable when we're trying to introduce new ideas. The sub-contractors always ask who is going to pay. Or they assume that we should pay.

For their part, the sub-contractors did not deny that this situation exists with regard to service development. Indeed, they claimed that the contractual arrangements actually impeded the development of a public-transport service of high quality because there were few incentives for the operator to go beyond the prescribed service level. One of the operators in the fifth case study made the following observations:

We are interested in developing public transport and services ... [but] it is difficult to develop the business outside the contract; indeed it is almost impossible. The Public Transport Authority dictates the conditions for the service that is to be delivered ... We have to look at the basis of the tendering process and what the PTA wants to buy for the next eight years, and then we create a product based on this and offer it to the PTA at a certain price ... Our driving force is being as efficient as possible. This is what we are evaluated on - not on our plans and ideas about how to develop the services.

According to this view, the existence of a strict formal contract and specifications for the services to be delivered forces the sub-contractor to make an offer that meets the minimal requirements at the lowest possible price. Every transaction that is not part of the day-to-day operations agreed in the contract can create problems in terms of negotiations and bureaucratic communication between the parties. Any service development undertaken by the 
sub-contractors must be paid for separately by the PTA; alternatively, such service development must be performed gratis by the sub-contractor in an attempt to deliver a better service and thus fulfil the PTA's vision.

From the perspective of the PTAs, these commercial realities mean that the sub-contractor seldom appears to do anything over and above its contractual obligations, leaving the authority responsible for any unforeseen costs entailed by providing an adequate or improved service. The commitment of sub-contractors to development projects is thus significantly restricted, especially with respect to larger projects that require resource commitment in the long term, with no prospect of immediate profit.

The unwillingness of the parties to collaborate in undertaking more extensive service development thus reflects the institutional environment in which the parties are forced to interact. The contractual situation, which is clearly governed by a framework of laws and regulations, creates an atmosphere of formality and inflexibility in which strict guidelines determine how the business should be conducted. Moreover, the regulations governing the tendering process discourage any form of consultation and co-operation between the contracting parties prior to the signing of the contract. This situation is in accordance with the observation of Laing and Lian (2005), who contended that the relationships in such formal tendering processes are characterised by a low level of trust, business at arm's length, and a short-term orientation (even though the contract itself might be relatively long-term in duration).

\section{Conclusions and Managerial Implications}

The objective of this study was to investigate what happens in new-service development when commercial imperatives and public imperatives meet - each with different incentives for developing new services. More specifically, the study has utilised seven case studies in the Swedish public-transport system to address two research questions:

- What is developed in these situations? and

- How are these developments undertaken?

A general conclusion that can be drawn from this investigation is that the challenges associated with new-service development appear to be greater in the public sector than in the private sector. One reason for this is that public-sector service development typically involves a broader spectrum of actors and more bureaucracy than is the case in the private sector. As Smith and Fischbacher (2005) have noted, successful innovation requires that the particular opinions and agendas of all actors in the network must be taken into account during the development process.

More specific conclusions to be drawn from the empirical investigation include the identification of three different types of service developments. The type of most interest to the objectives of this study were the owner-driven development projects that were designed to fulfil certain political and social imperatives. These included development projects to facilitate the use of public transport by elderly and disabled citizens, and projects to minimise environmental pollution. The development of these services reflected the fact that public transport is subject to a framework of laws, regulations, and policy-making that aims to deliver services that best meet the needs of society in general, rather than merely being concerned with the day-to-day needs of public-transport users. In contrast to these considerations, it was apparent that the sub-contractor, whose purpose was to make a commercial profit through its contacted business, was driven by a different set of imperatives. As a consequence, these new-service developments were, to a certain extent, forced upon the operators by contractual stipulations and sanctions.

The second type of developments were customer- or market-driven projects that aimed to make public transport more competitive and attractive. Examples of these projects, which were managed by either the sub-contractor or the PTAs, included the introduction of business class on the buses and the employment of bus attendants on some longer routes.

The third kind of projects were long-term strategic developments, such as sophisticated communication and ticketing arrangements. These projects had the potential to fulfil both the political/social objectives of the owner-perspective and the customer-oriented objectives of making public transport more efficient and easier to plan.

Despite these development projects of various types, the empirical data from the case studies indicates a generally low level of collaborative service development during the duration of the contracts between PTAs and commercial sub-contractors, which provided little scope for creative discussion and partnership. It was apparent that the Public Procurement Act, and the way in which it was interpreted, actually hampered the possibilities of developing a high-quality public-transport service. The law severely limits the factors that can be taken into account during the tendering process - such as the commitment of the bidders, or the ideas they might have for developing and 
improving public transport during the period of the contract. Moreover, all requirements regarding the service have to be stated before the bidding process is initiated, which results in stultified service development. These findings suggest that the formulation of the terms of the contract represents an especially important aspect of the service-development process. Indeed, the formulation of the contract could actually be seen as service development in itself, given that the contract provides the guidelines for how the service is to be developed during the coming years.

Despite these difficulties, some PTAs in the present study did claim to have created a collaborative culture with their sub-contractors that encouraged service development. In this regard, it is interesting to note that these PTAs made greater use of contractual incentives and rewards for sub-contractors who improved the service and increased passenger numbers. Although this does demonstrate a commitment to creating a positive relationship-oriented culture to enhance innovation and development, it must also be said that even in this case the contract and its formulation remained the key factor in service development in this setting.

From a managerial perspective, the findings of this study emphasise the importance of being aware that not all service-development projects are the same. Different types of development projects exist, and managers should be aware that there are sometimes conflicting public and commercial imperatives involved. Managers should take this into account in seeking to develop collaborative service-development processes in their organisational networks. It is also important for managers to recognise that a large proportion of service-development planning is actually undertaken before the contractual period begins; indeed, this is often done unilaterally by the purchaser, who decides (without consultation) what service output it wishes to achieve during the contractual period. These unilateral decisions are usually stated in the contract as technical specifications, expected standards, and prescribed quality measures. Managers should therefore recognise that the formulation of tendering documents and contracts represent the most important determinant of service development, often for many years in advance.

\section{References}

Abramovici, M., \& Bancel-Charensol, L. (2004). How to take customers into consideration in service innovation projects. Service Industries Journal, 24(1), 56-78. http://dx.doi.org/10.1080/02642060412331301132

Akamavi, R. K. (2005). A research agenda for investigation of product innovation in the financial services sector. Journal of Services Marketing, 19(6), 359-378. http://dx.doi.org/10.1108/08876040510620148

Bowers, M. R. (1989). Developing new services: improving the process makes it better. The Journal Of Services Marketing, 3(1), 15-20. http://dx.doi.org/10.1108/EUM0000000002478

Cooper, R. (1996). Overhauling the new product process. Industrial Marketing Management, 25(6), 465-482.

Cooper, R., \& Edgett, S. (1999). Product development for the service sector- lessons from market leaders. New York: Perseus Books. http://dx.doi.org/10.1016/S0019-8501(96)00062-4

Daymon, C., \& Holloway, I. (2002). Qualitative Research Methods in Public Relations and Marketing Communication. London: Routledge.

de Brentani, U. (1989). Success and failures in new industrial services. Journal of Product Innovation Managemen, 6(4), 239-258. http://dx.doi.org/10.1111/1540-5885.640239

Edgett, S. (1996). The new product development process for commercial financial services. Industrial Marketing Management, 25, 507-515. http://dx.doi.org/10.1016/S0019-8501(96)00067-3

Edvardsson, B. (1996). Kvalitet och tjänsteutveckling (in Swedish). Lund: Studentlitteratur.

Edvardsson, B. (1997). Quality in new service development: key concepts and a frame of reference. International Journal of Production Economics, 52, 31-46. http://dx.doi.org/10.1016/S0925-5273(97)80765-7

Edvardsson, B., Gustafsson, A., Johnson, M. D., \& Sandén, B. (2000). New service development and innovation in the new economy. Lund: Studentlitteratur.

Eisenhardt, K. M. (1989). Building theories from case study research. Academy of Management Review, 14(4), 540.

Gothenburg University, Dept. of Psychology, 1101-718X; [119], Gothenburg. http://dx.doi.org/10.2307/258557

Grönroos, C. (1990). Service management and marketing: managing the moments of truth in service competition. Lexington, Massachusetts: Lexington Books.

Johansson, J., \& Vahlne, J-E. (1992). Management of Foreign Market Entry. Scandinavian International Business Review, 1(3), 9-27. http://dx.doi.org/10.1016/0962-9262(92)90002-N 
Johne, A., \& Storey, C. (1998). New service development: a review of the literature and annotated bibliography. European Journal of Marketing, 32(3), 184-251. http://dx.doi.org/10.1108/03090569810204526

Johnson, S. P., Menor, L. J., Roth, A. V., \& Chase, R. B. (2000). A critical evaluation of the new service development process. In J. A. Fitzsimmons and M. J. Fitzsimmons (Eds.), New service development - creating memorable experience. Thousand Oaks, California: Sage Publications inc.

Jong, de, J. P. J., \& Vermeulen, P. A. M. (2003). Organizing successful new service development; a literature review. Management Decisions, 41(9), 844-858. http://dx.doi.org/10.1108/08876040510591420

Kristensson, P. (2003). Creativity in applied enterprise - bringing impetus to innovation. Diss.

Laing, A. W., \& Lian, P. C. S. (2005). Inter-organisational relationships in professional services: towards a typology of service relationships. Journal of Services Marketing, 19(2), 114-127. http://dx.doi.org/10.1080/13662710500087925

Leiponen, A. (2005). Organization of knowledge and innovation: the case of Finnish business services. Industry and Innovation, 12(2), 185-203.

Lievens, A., Monaert, R., \& S'Jegers, S. (1999). Linking communication to innovation success in the financial service industry: a case study analysis. International Journal of Service Management, 10(1), 24-37.

Magnusson, P. R., Matthing, J., \& Kristensson, P. (2003). Managing user involvement in service innovation. Experiments with innovating end users. Journal of Service Research, 6(2), 111-124. http://dx.doi.org/10.1177/1094670503257028

Martin, C. R., \& Horne, D. A. (1993) Service innovation: successful vs unsuccessful firms. International Journal of Service Industry Management, 4, 48-64.

Matthing, J. (2004). Customer involvement in new service development. Diss. Karlstad University studies, 1403-8099; 2004:31, Karlstad.

Merriam, S. B. (1994). Qualitative Research and Case Study Applications in Education. San Francisco, CA: Jossey-Bass Publishers.

Miles, M. B., \& Huberman, A. M. (2004). Qualitative Data Analysis. London: SAGE Publications.

Patton, M. Q. (1990). Qualitative evaluation and research methods. Newbury Park: Sage Publications.

Sandén, B. (2007). The customer's role in new service development. Diss. Karlstad University studies, 1403-8099; 2007:14, Karlstad.

Schilling, A., \& Werr, A. (2009). Managing and organizing for innovation in service firms- A literature review with annotated bibliography. Report VR 2009:06, Stockholms School of Business, Stockholm.

SLTF. (2002). Public Transport in Sweden - Co-ordination and Competition. Stockholm. Swedish code of statutes 1992:1528 - The Procurement Act (Lagen om offentlig upphandling), Stockholm.

Smith, A., \& Fischbacher, M. (2005). New Service Development: a Stakeholder Perspective. European Journal of Marketing, 39(9/10), 1025-1048. http://dx.doi.org/10.1108/03090560510610707

Stevens, E., \& Dimitriadis, S. (2004). New service development through the lens of organisational learning, evidence from longitudinal case studies. Journal of Business Research, 57, 1074-1084. http://dx.doi.org/10.1016/S0148-2963(03)00003-1

Sundbo, J. (1997). Management of Innovation in Services. The Service Industries Journal, 17(3), 432-455.

Sundbo, J. (1998). The Organisation of innovation in services. Roskilde: Roskilde University Press. http://dx.doi.org/10.1080/02642069700000028

Syson, F., \& Perks, H. (2004). New Service Development: a Network Perspective. Journal of Services Management, 18(4), 255-266. http://dx.doi.org/10.1108/08876040410542254

Yin, R. K. (1994). Case Study Research: Design and Methods. Thousand Oaks, CA: Sage Publications. 